\title{
Social Entrepreneurship in the Leadership of Grassroots Innovation Movement: A Case Study of Joglo Tani in Yogyakarta
}

\author{
Setiadi \\ Department of Anthropology, Universitas Gadjah Mada, Indonesia \\ Email: setiadi_antro@ugm.ac.id
}

\begin{abstract}
This article is based on a case study in Joglo Tani, a local organization that focuses its programs on promoting new agricultural technology and urban farming while promoting food security for local people. It represents what characterizes the grassroots movement while destroying negative opinion about grassroots innovation. The success of Joglo Tani is influenced by the quality of leadership as social entrepreneurs as well as the quality of the network of activists and an organization that produce new, bottom-up solutions, and the ability of the solutions they produce to address local situations, concerning individual and social problems. The organizing of Joglo Tani innovations in the local realm has brought about a process of social transformation in rural areas, particularly in resource management and the system for organizing agricultural work. Through a voluntary movement, informal networks, and the ability to manage the potential of the environment, leadership is able to carry out the transformation process on an increasingly massive scale. This study proves that leadership in a bottom-up movement of 'activist and organizational networks' has succeeded in responding to the challenges of food supply limitations, moving towards sustainable food through instilling fundamental values of organizational life and technological breakthroughs as well as local institutions. Methodologically, the research was conducted through a comprehensive literature study stage related to grassroots innovation movements, while primary data collection was carried out through participatory observation, in-depth interviews, social and conventional media analysis, and interviews with community figures.
\end{abstract}

Keywords: grassroots movement; quality of leadership; social entrepreneurship

\section{INTRODUCTION}

The local organization movement is believed to have the ability to address problems in the local community. One of the local problems is food security, especially at the household/individual level (Amrullah, Ishida, Pullaila, \& Rusyiana, 2019). Food security will always be a strategic issue as population increases (Ashari, Saptana, \& Purwantini, 2016). Food security at the household level is the foundation of community food security, which then becomes the pillar for regional and national food security (Dewan Ketahanan Pangan, 2009). In order that these efforts succeed, the role of civil society indeed becomes strategic. In this context, it is important to look at various local efforts, especially as to how various grassroots innovations, which are initiated individually and collectively, find solutions to both individual and community problems (Ross, Mitchell, \& May, 2012), including those related to food security. Conceptually, this 'grassroots innovation' is a network of activists and organizations that produce new solutions, that have a bottom-up nature for sustainable development, that respond to local situations and the interests and values of the communities involved (Seyfang \& Smith, 2007). Grassroots innovations have been increasingly important because of their potential for achieving sustainable 
development (Muok \& Kingiri, 2015). The grassroots innovation movement can be perceived as a creative response to the modernization of the economy, politics and technological development and diverse social and environmental consequences with their many undesired impacts (Ziegler, 2017) for example, the impact of innovation in developing countries (Muok \& Kingiri, 2015) related to technological change. In addition to being able to increase efficiency, it can also mean layoffs. The management of distribution models (Lee, et.al., 2018) also leads to differences in the concept of social justice and environmental problems. Eventually, responses to finding solutions emerge at the grassroots level (Smith, Fressoli, \& Thomas, 2014).

Civil society organizations are the main actors in grassroots innovation (Hoppe, et.al., 2015). This is in line with the anatomy of this movement, in which initiatives tend to operate in the arena of civil society and involve committed activists who experiment with social innovation, using more environmentally friendly technology and techniques (Seyfang \& Longhurst, 2016) and triggered by local interests at a particular time and place (Castro-Arce \& Vanclay, 2020). In regard to Civil Society Organizations, there are currently 3,000 nongovernmental organizations in Indonesia (Sparrow \& Widyanti, 2010) and are engaged in various fields such as environmental politics (Ardhian, Adiwibowo, \& Sri Wahyuni, 2016), empowerment of oil palm farmers (Obie, Yusuf, \& Sumai, 2019) and "farmer empowerment" through the strengthening of social capital (belief systems, networks and values) and kinship (Widiara, et.al., 2009). Through collective action, problems can be effectively solved, particularly those found among the poor living in densely populated urban areas or in agricultural systems (Coppock \& Desta, 2013).

At the global level, the grassroots innovation has been developing rapidly. Examples of such innovation include community energy initiatives (Martiskainen, Heiskanen, \& Speciale, 2018) in the eco-village movement (Magnusson, 2018) and seen in the community energy development (Magnusson \& Palm, 2019) in Sweden. In addition, grassroots innovation has arisen in the fields of transportation (Ross, et al., 2012), water conservation in India (Verma, Tsephal, \& Jose, 2004), education (Ghiso, et.al., 2013), (Ličen, Findeisen, \& Fakin Bajec, 2017), and community-based energy management (Nolden, 2013). Other studies provide examples of structured grassroots innovations (Ustyuzhantseva, 2015): the ecofriendly village (Magnusson, 2018); sustainable food crop agricultural system (Laforge, Anderson, \& McLachlan, 2017); democracy innovation issues (Smith \& Stirling,
2016); human settlement innovation, food and energy (Smith, 2016); and community energy (Hargreaves, et.al., 2013). Initiatives such as community energy projects, community gardens, and local food marketing networks are examples of combinations of technological and social innovations (Martiskainen, et al., 2018). Looking at the examples of grassroots innovation, it seems that community actions for sustainable development shows promise in the context of socio-technical innovation (Seyfang \& Longhurst, 2016). Scrutinizing the socioeconomic characteristics of communities, Lehner showed the importance of grassroots innovation (and frugal innovation) in Indonesia, India and Egypt (Lehner, Koldewey, \& Gausemeier, 2018), and other developing countries to reduce mainstream innovation which generates economic gaps. It is the inclusiveness of grassroots innovation which is needed (Schillo \& Robinson, 2017).

In my observation, the study of the dynamics of various institutional and organizational aspects is one of the important issues in grassroots innovation study. In the context of grassroots innovation, it is necessary to reorient new studies of organizations from academic orientation and the needs of the business elite to the study of how to change society (Tracey \& Stott, 2017). Organizations have an important role as agents for social change and development (D'Souza, 1984). Studying organizations, as agents for social change, is studies of innovation that are triggered by individuals and communities in finding socio-economic solutions and promoting social entrepreneurship (Ross, et al., 2012). Refer to Seyfang and Smith, the term "grassroots innovations" is to describe the networks of activists and organizations generating novel bottom-up solutions for sustainable development. These innovations are also solutions designed to "respond to the local situation and the interests and values of the communities involved," Community-led "grassroots innovations" emphasize social innovations developed at the local level (Hoppe, et al., 2015:1903). In this context, it is important to understand that grassroots innovation is a form of citizen participation (Hoppe, et al., 2015) in solving local problems. An initiative of grassroots innovation, sustainability involves forms of organization, use of technology, skills, infrastructure, marketing and other organizational requirements (Smith, et.al., 2016). The strength of grassroots innovation is that the solutions offered are low cost, strong, easy to use and efficient (De Keersmaecker, et.al., 2013).

Departing from these strategic thoughts, this article, which is based on a case study on the Joglo Tani Group (a community empowerment group in Yogyakarta), intends 
to answer the questions of how social entrepreneurial values, reflected in the leadership of the empowerment movement, can last for a period of several decades and also how actors manage the dynamics of the movement so that they are able to carry out and express their values for the sustainability of their organizational activities. To answer these problems, I use the perspective of social entrepreneurship theory that can be defined as "the creation of a social value that is produced in collaboration with people and organisations from the civil society who are engaged in social innovations that usually imply an economic activity", with four key elements, namely social values, civil society, innovation and economic activities (Hulgård, 2010) and the concept of social entrepreneurial value (Nakamura \& Horimoto, 2020). This theory explains the efforts and central role of the driving figures in Joglo Tani. A social entrepreneur does not focus on business results, but rather on how the final results of social business generates sustainable change in people's lives, and this change must be at the community level instead of the individual one (Ebrashi, 2013). Social entrepreneurship is an effort to find sustainable solutions to problems that have been neglected, which usually begin with small initiatives, and what is important is how to explain value creation and value capture in social entrepreneurship (Santos, 2012).

\section{RESEARCH METHODS}

This research focusses on a grassroots organization located in Yogyakarta named Joglo Tani. Joglo Tani, an acronym in Javanese which stands for "Ojo Gelo dadi Petani" (don't be disappointed being a farmer). This organization was chosen for several reasons. Firstly, it has been involved in community empowerment and has created many innovations in terms of organizational development models, supporting technologies for agricultural production process, social technology, and institutional experience, becoming a reference for agricultural-based economic development in Indonesia. Secondly, it has produced alumni who became pioneers of innovation in various regions and initiators of local community empowerment. Thirdly, this organisation has become a reference for activists and facilitates significant progress for the agricultural sector in small communities. I conducted a series of interviews, observations and Focus Group Discussions with activists involved in Joglo Tani's activities, members of its administration board, and target groups in the Yogyakarta Special Region. I also conducted a series of activities by visiting community groups that were assisted. Using this method, information on aspects of its program and technology sustainability was obtained.

The research was conducted in several stages.

The first stage was a comprehensive literature review on: grassroots innovation; grassroots innovation movement; institutional issues, and; community involvement issues in disseminating and accepting innovation. The second stage was participatory observation. This activity was carried out by research assistants on organizational processes and institutional work of Joglo Tani groups. Through this activity various data and information related to intrinsic aspects of the organization was collected. The third stage was analysis of social and conventional media, particularly broadcasts, interviews of central figures of Joglo Tani, and statements of training participants and visitors to Joglo Tani. The fourth stage was incidental observation conducted beyond research activities in the form of frequent visits when I took postgraduate students of Anthropology of Gadjah Mada University students to Joglo Tani for field trips and social dynamics classes and social engineering classes. In addition, I also made personal visits to Joglo Tani.

\section{FINDINGS}

I gained a very good impression when I first entered the surroundings of Joglo Tani as to how effectively and efficiently the farming land had been used. It is located on land that is around 500 square meters, in the middle of which stands a joglo house building with various food crops and a system built for fish and animal husbandry. Although this land is not very extensive viewed from the perspective of agricultural business, it is used intensively, very effectively, and is very well ordered. Entering the area of Joglo Tani was like traveling into an organic garden. In the joglo building, several banners decorate the main room, one of which reads: "intention, work, honesty, worship, and sincerity", philosophical values that describe the principles applied in its activities. Various forms of simple technological innovation are practiced in the production process of agriculture, animal farming, and fisheries. Various vegetables and fruits are planted using simple planting media on the land around the joglo building. Likewise, livestock such as chickens, ducks and cows are raised in a simple way. Some ponds contain red tilapia, gourami and catfish. Catfish were also farmed in plastic barrels combined with vegetable plants. One of the ponds is used for food production with floating rice planting technology combined with fish and chicken farming using a battery-shaped cage above the pond.

The success of Joglo Tani has lasted for decades retaining a simple system of managing the organization 
and the environment. In its development, Joglo Tani has adopted an institutional management system that is unique and has been able to sustain the operation over a very long period of time. In general, this research found a model of organization, programs and activities that were very flexible, simple, adaptive to change and upheld the values of humanism. The principles of life based on Javanese values were firmly embedded in this organization. In keeping with grassroots organizations in general, this organizations was run well because of the existence of a driving force who had laid the foundation of its values.

\section{The Rise of Innovative Leadership}

One of the important factors in the development of Joglo Tani has been its leadership. Leadership in a grassroots innovation movement generally comes up naturally, is unpaid, it has work responsibilities, and is imbued with a passion in carrying out its functions (Gould \& Malachowsky, 2013). The figure behind the establishment of Joglo, Tani, T.O. Suprapto fulfills these criteria. He founded and developed an organisation that he named Joglo Tani (Ojo Gelo dadi Petani). He was a sports teacher who was interested in developing agriculture since 1989, when he began to join farmers' groups in his village. Joglo Tani was established due to his care and concern for the condition of farmers. On a program with the theme of learning food self-sufficiency by Joglo Tani. T.O. Suprapto states:

"Joglo Tani is a natural laboratory. A monument of the revival of Indonesian farmers with integrated agriculture. Therefore, in Joglo Tani there is a reality, facts, food crop agriculture integrated with horticulture, fisheries and animal farming....agriculture means human intervention in cultivation and, therefore, farming must operate with the philosophy: "Talesing widyo ayulat tinulat ing wigyo lan sembodo" (good hope is only achieved with consistent seriousness)... agriculture is not discussed, but carried out instead...."

He also explains the foundation and principles of technology in the development and cultivation of agriculture, including the philosophy that became the basis for the development of Joglo Tani's activities. In a YouTube video (MNCTV, 2014a) he explains the philosophy in developing agriculture and integrative cultivation technology:

"(Dandang Gula, a Javanese song, is accompanying the interview ...Lamun kaki, harso nandur
pari...)....Seven days in this place, seven days of dreams (or making plans), seven months of realizing it, and finally seven-year-old children will enjoy it. My fear is that when there is no generation that continues and manages our land, this land will be controlled by others, not even our nation, hence our young people become their coolies. So, this is my concern....Agriculture is cultivation.It cannot be separated from livestock. From the integration of animal farming and agriculture, from livestock waste in the form of solid or liquid manure, with some technology, the manure can become the initial capital of agriculture.... Agricultural waste could be the beginning of animal farming.... with the use of Cokro Manggilingan (spinning wheel) philosophy, ..wiji wutuh, wutah pecah, dadi wiji maneh (whole seeds, seeds break, become seeds again).."

T.O. Suprapto explains that Joglo Tani grew from a sense of concern seeing the condition of farmers in Indonesia who experienced six pressures, namely economic, natural, social, cultural, global or free market, as well as government policy pressure that did not favor farmers, so that farmers seemed to only be suffering in life (Syadiah, 2015). For this reason, he started with local food security, which he understood would be realized if there was family food security. Historically, the idea of establishing Joglo Tani did not happen in the blink of an eye. He said,

“(When I was) in the farmers' group, I participated in a national Integrated Pest Management Field School program specifically for rice from 1989 to 1999 . I was originally a participating farmer, and succeeded in becoming a guiding farmer and formed a Guiding Farmers' Association Yogyakarta. After the program ended, the Guiding Farmers held a discussion on IPM (Integrated Pest Management) for farmers in Yogyakarta. The meeting also invited representatives of 12 provinces other than Yogyakarta, which also received the training, namely: North Sumatra, West Sumatra, South Sumatra, Lampung, Banten, West Java, Central Java, East Java, West Nusa Tenggara, Bali and Sulawesi. In this discussion the farmers complained that the training program had not been able to reach all farmers throughout Indonesia".

The discussion forum, which was an informal activity, apparently had the power to mobilize people. 
From the discussion of the problems then arose a new independent project without government intervention because it did not have any funds to continue the program. The project was called Farmers Association for Integrated Pest Control). The project had 5 programs to be implemented, namely: 1) Integrated Pest Management Field School), 2) Farmer Science, a research conducted by farmers themselves, 3) Training for farmers based on gender because farming could also be done by women, 4) Internal and external advocacy, advocating for themselves and for other parties, 5) Field Support Management, which was a summary of the other four programs. These programs consistently became the core of Joglo Tani's activities (Sunarno, 2011).

There was a time when T.O. Suprapto gave up his job as a teacher and toured Indonesia to do coaching. It was very clear that voluntarism was one of the keys to the success of this group. He revealed, "But that's hard! I traveled around Indonesia but was not paid from 1999 to 2007. I was like a candle that illuminated the surroundings but then slowly it was gone.My family was falling apart. My child reminded me of that," he recalled. In the end, he decided to pioneer Joglo Tani with an integrated farming model. Joglo Tani also had the same goal, namely to form a farming community that could improve the skills, knowledge and income of farmers. Eventually, Joglo Tani became a training center for young farmers from various places in Indonesia.

\section{Social Technology Development}

The technology developed by Joglo Tani was appropriate, it was easily replicated, based on inexpensive materials (even from waste such as plastic bottles), simple, and always adaptive to users' needs. This technology is in harmony with the social concept of grassroots innovation or later known as social technology (Hilmi, 2012), which is often equated to the concept of frugal innovation (Meagher, 2018). He tried to find various simple innovations for the development of integrated agriculture. His activities as an activist involved in a grassroots innovation movement, showed the indicators of grassroots innovation development, including an attempt to develop innovation in the community (Smith, 2016), promoting further grassroots innovation and encouragement of local development (Ličen, et al., 2017). The developments he had carried out in science and technology at the grassroots level (Joshi, Chelliah, Sood, \& Burdon, 2016), were able to provide solutions for sustainable development at the local level (Kanagasundram, Ng, B.-K., Wong, \& Chandran, 2016). In addition, he also had fulfilled the criteria of having a trans-local grassroots network which enabled him to be proactive in building local resilience. The fundamental characteristic of the community where Joglo Tani grew, was socio-cultural cohesion, which enabled them to access local resources and legitimacy as well as the creation of social values in the community (Maxim Vlasov, 2018).

His activities strengthened his central position in the organization positioning him to bring about extraordinary achievements and also survive for decades. His innovations met the criteria for sustainability which involve several forms of collective behaviour and related network links (Leliveld \& Knorringa, 2018), focusing on individuals as innovation agents (Kumar \& Bhaduri, 2014; Leliveld \& Knorringa, 2018; Bhaduri \& Kumar, 2011). This is based on his capacity to internalize and ally organizational values:

"T.O. Suprapto, the farmer from Sleman, Yogyakarta created what was later called 'common sense management'. His innovation was born in 1996. He named it SRI or System of Rice Intensification. In SRI, T.O. as he is often called, has applied the method of planting one tree, planting young, and planting shallow. This method was then also known to foreign countries. The T.O. method has proven to be successful in increasing agricultural yields and last but not least is environmentally friendly" (Liputan6, 2011).

To build this relationship, he applied five principles that Joglo Tani could develop not only within the organization but also outside it, such as in the community. Therefore, there were five principles that were applied, namely "intention, work, honesty, worship, and sincerity". Then, from the five principles it was expected that the local people or members of the local community could achieve a change in attitude, have understanding of and be skillful in both management and the development of production facilities. He had a view that if someone had mastered these basic principles, $\mathrm{s} / \mathrm{he}$ would be able to apply in many aspects of human resources (HR), natural resources, community (social), physical, and financial issues. It becomes clear that in its management, the innovation process could be understood as adaptation and adoption of ideas, and, most critically, the process of how to use these ideas (Muok \& Kingiri, 2015). It was not surprising that with this ability he received recognition from various parties, one of whom, MNCTV, made him an agricultural hero (MNCTV, 2014b).

The strength of Joglo Tani's innovativeness can be seen from the recognition and testimony of several training participants: 


\begin{abstract}
"There is something great that we need to take from Joglo Tani, which is chaired by TO Suprapto; how can it be possible for just a farming community to be able to unite and accommodate hundreds of farmer groups in the surrounding area. Joglo Tani is able to bring farmers in the area to become authoratitive, independent and self-sufficient. With its group activities, Joglo Tani can unburden farmers from the Land and Building Tax, help educate their children to tertiary level, be able to pay administrators Rp650,000-Rp700,000/ month, control the price of agricultural production, produce 2 tonnes of granule organic fertilizer and liquid organic fertilizer 1,000 liters/month, produce organic rice, vegetables and fruits, and there are many more achievements by Joglo Tani which I have not written here. What is clear is that Joglo Tani is able to make farmers truly proud of their profession" (Maspary, 2011).
\end{abstract}

The strength of Joglo Tani is its ability to maintain values, such as implementing processes of critical learning in program implementation in the organization (Nirmala, Yukti, \& Wahyono, 2020) which leads to sustainable programs, it's mean: stable and enduring. It is a proof that the power of technological innovation and social innovation is sustainable (Morrar, et.al., 2017). As an initiator, T.O. Suprapto had a strong vision in developing Joglo Tani. He stated the following:

"..Agriculture is cultivation......a way of thinking. Engineering ability..., the ability to use media...for annual crops...food security condition, we meet the needs because we can afford to buy (things), (whereas) food self-sufficiency is the family's living needs that can be met because we plant, we harvest. The key to food self-reliance must start with one's own family. (We need to know) whether a family has dreams or not, has aspirations or not, to run a business or not, because being complicated, lazy will obviously become the main obstacles to independence. Independence is honesty, independence is struggle, independence is action. Therefore, in any cultivation, independence will never exist if the person concerned is always dependent and lazy. So, laziness will become the main obstacle. But diligence will be the key to independence....(we) will have physical and mental sufficiency..." (Bumiku satu TV, 2012).

From Suprapto's words, it appears his focus of effort is to encourage food self-sufficiency. Food self- sufficiency is integrated with fertilizer sufficiency by creating simple social technology based on household waste such as vegetables and banana peels to create micro-organisms to decompose leaves. He also created anona bacteria from pineapple peel, $5 \%$ sugar and water. Through a one-week fermentation process it becomes liquid fertilizer. This is a very simple technology that was provided to other farmers and those who wanted to practice to replicate it. Although this method may still need to be scientifically verified, in practice, this knowledge has been applied to the management of agricultural systems in Joglo Tani. It is clear that he applied what was to realize the vision by applying the concept of replication or re-application of technology, which allowed full participation of local communities, and those who repeated various processes would see social technology achieving large-scale influence. According to (Jong \& Fonseca, 2020), 're-application' of technology implies (a) an adequate reproduction for local space, b) appropriation by local population, and c) assessment of results of implementing it. The production of knowledge within the local communities involved was intended to be intensive and empowering. This model is certainly different from the various perspectives on social technology and social entrepreneurship, which see social technology as a diffusion of the results of innovation (artefact) through market power (Bhalchandra et al., 2010; Singh et al., 2009; Yagnick et al., 2019).

T.O. Suprapto showed in detail how simple technologies could be adopted and applied by farmers or people. He implemented what was meant by "social technology" (Kasavin, 2017) which implies a communicative activity of social entities at the level of organization, administration, social planning activities in the context of social construction of knowledge and reality. What was developed at Joglo Tani, technologies and concepts of independence, showed the existence of a frugal innovation concept, having affordability and accessibility, and serving to meet the special needs of lower socio-economic classes (Gupta, 2019).

\section{Principles of Organization Development and Productive Business}

The logo of Joglo Tani has three heads depicted with small circles and three hearts drawn together. The meaning of the logo is a small head with a big heart. (i) creation, taste, intention. (ii) yesterday, now, tomorrow. (iii) mother, father, child, and (iv) heart, action, speech. It is also based on the philosophy taken from Ki Hajar Dewantara (i) Ing ngarsa sing tuladha (at the front there is an example), (ii) ing madya mangun karsa (motivating 
from within), (iii) tut wuri handayani (influencing from behind). That is the meaning implied by the logo of Joglo Tani, which is all taken from the Javanese philosophy that Pak TO liked.

"So, the heart, the brain, and the speech must become one, because 'raga warege merga sega' (the energy of the body comes from rice (food)), 'yen sukmo warege mergo dongo' (the energy of the soul comes from prayer). That is a philosophy that I have always held. And in my opinion, life is for worship. If you haven't died yet you won't find life" (T.O. Suprapto).

Joglo Tani has made a concept of 'success' that is not centered on individuals but on many people instead. Organization development though cannot be separated from the existence of various obstacles. To overcome this, he relied on the value of cause and effect.

"I have always held on to the palsing sidyo ayu tinurat ing witnya lan sembada which means good hope will only be realized with sincerity that is consistent with the law of cause and effect. I return everything to effort and prayer" (T.O. Suprapto).

Understanding the management of obstacles based on relevant principles can lead to further discussion of grassroots innovation that is not merely material in the form of what is commonly described by the concept of innovation but it can also be in the form of intangible things such as organizational systems, conflict management, or even culture itself.

Produce is marketed by students at Joglo Tani but it is not about maximising individual profit but rather to create a sustainable form for a family unit which can produce surplus for the market. During a field trip with an Anthropology graduate student, I met apprentice students from SMKN 1 Naggulan (vocational high school), Kulonprogo. A total of 13 students of grade 11 were apprenticed for 6 months in Joglo Tani. They did a variety of things, including making a garden, planting vegetables such as spinach, chili, leeks, chives, and also managing the farm. Children were taught to make a thematic farming activity that was "Sustainable Food Barn Area". The core activity concerned how to maximize land use in order to support a family so that it could become a daily food source. Organic morning glory had been harvested and sold to some stalls at Rp 1,000 for each bundle. Each apprentice student was assigned to make a report after completing the apprenticeship. They made a garden from scratch and also made a fishpond.
Activities were carried out around Joglo Tani and in the surrounding rice fields. The apprentices were given various training on organic farming.

In developing a business, Joglo Tani applies a principle profit for everyone. for example, economic benefits. Joglo Tani produces duck eggs on a regular basis that were purchased daily by martabak (savoury pancake) sellers, herb sellers, and gudeg (jackfruit) sellers. In addition, there were also wholesalers who purchased eggs there. Duck eggs were sold for Rp 2,200-Rp 2,300/per egg, depending on their size. Joglo Tani left the needs of accommodation and food for the trainees in the hands of the local community. The local residents provided their houses as homestays for trainees. It was from selling produce they got an abundance of income from the training programs. Joglo Tani is a non-profit organization, however the training activities have an economic impact on both participants and the surrounding community.

Extensive network development was carried out by T.O. Suprapto and Joglo Tani groups. According to him, Kampung Juragan was being developed in Bogor. This community was intended for former Indonesian migrant workers in Hong Kong and were unemployed. There were around 150 hectares of land on Mount Salak, 20 hectares of which was being used for the residence of 1200 families and 130 hectares for integrated agricultural land. These efforts were the embodiment of the strengths of the 4 pillars developed in Joglo Tani, which were "all who are active in Joglo Tani must be strong in their religion, healthy in terms of economy, good behavior and culture, and occupations. People of productive age must create work and be ready for education since science is everywhere."

\section{Appropriation by Local Population}

A community-based approach has the advantage of being able to articulate the voice of the local community, and unique representation and contribution of local communities into the self-design and adaptation to various mechanisms for the sustainable use of resources. Local initiatives are effective in improving human wellbeing (Shukla \& Sinclair, 2010). Social movements and grassroots are concerned more about empowering local communities and increasing the potential of indigenous communities to innovate (Pansera \& Martinez, 2017).

Embracing a food self-sufficiency movement by the community cannot be done without considerable effort. Currently Joglo Tani is targeting young people to be taught to become activists of food self-sufficiency. In collaboration with a government ministry, Joglo Tani held the Garda Mapan (Youth Movement of Food Self- 
Sufficiency) program which is now in its third year. Mr. T.O. Suprapto explained:

"The program selected 1,500 people each year to get 15 people to be trained to become members of the Garda Mapan. From 13 to 30 May, 2019 these participants were trained in Joglo Tani, Godean, and they were expected to become reliable farmers. What was obtained from the learning was then applied in their respective villages. Participants returning to their villages were provided with a 2,500 square meters of rented land, including infrastructure. This program was later upgraded to the Youth Entrepreneurship Center. After conducting individual cultivation, they had to develop it with other groups, it could be 2,3 or 4 groups, as a business unit. Nursery, production, post-harvest units to marketing" (Interview with T.O. Suprapto).

Institutionally, Joglo Tani continues to grow and develop itself. The organization also collaborated with the Department of Agriculture by developing the Lumbung Mataraman program in Yogyakarta. There were five regions of development and would continue to develop until it reaches 21 regions or development points. At present, Joglo Tani has become an educational activity. Communication is done remotely and consultation is done by telephone. The support of the local government was also provided in the form of three hectares of land given as village property which was handed over to be developed into a tourist village. Institutional capital development continued to be done in line with the increasingly strong need for various implementation activities. The land that is currently in use is still rented land. In the future, the activity will move to an area of 3,000 meters owned by one of the training participants. Interviews with training participants showed their success in developing agriculture.

"I was Mr. T.O. Suprapto's driver. I came with him here and there and became inspired to develop a business. Of course, with his permission. Now I own many businesses in agriculture. Developing the manufacture of organic liquid fertilizer, fertilizer powder and fertilizer tablets. My fertilizer is excellent because it only needs one-time fertilization for three harvest times. The price of 1 liter of liquid fertilizer is Rp90,000. It is made of rabbit urine. This business has been able to produce 17,000 liters of liquid fertilizer per month. Fertilizer making is not the only business
(I have). I am also engaged in the provision of superior baby rabbits, tilapia fish farming, produce trade, and agricultural training. Everyone is welcomed to have training here for free. For one, two or three weeks. After that, please go home and practice it at home. Produce food so that we are self-sufficient. I am also a regular training resource at the Sleman Regency Agriculture Office. I can provide sufficient salary for workers involved in this business. I give a bonus of Rp 6,500,000 per month plus the provincial minimum wage to a worker whose job is fermenting fertilizer. This worker is only a junior high school graduate" (Interview with Han).

The development of businesses owned by the training participants in fact even had a large business turnover. This is another fact of the success of Joglo Tani. It provides an illustration of the fact that Joglo farmers have been able to produce new social entrepreneurs. This is similar to what happens in the natural batik production process, in which a person who is initially merely a worker can become an owner (Handayani, Widhi; Kristijanto, Augustinus IGN and Hunga, 2018). It's just that in Joglo Tani people had to become "foster children" before becoming owners.

An organizational philosophy from which the principle of "education for all" arose seemed to be another characteristic of Joglo Tani. It was explicitly shown by strong recognition from the following element of civil society. The practice of the grassroots movement by Joglo Tani gives a strong message that bottom-up activities can be carried out and have an extraordinary impact both at the level of individual, family, and local community. These practices are ones that seek to fight the dominance of mainstream innovation. Joglo Tani's activities aim to build and promote alternative food supply systems to enable more sustainable forms of production and consumption at the local level. This is in line with what is meant as a co-evolution of social-technical innovation as a potential source of new ideas and solutions (Seyfang \& Longhurst, 2016).

Joglo Tani has transformed into a movement that is deeply rooted without a complicated organizing model. It represents what characterizes the grassroots movement while breaking down negative opinions about the grassroots innovation movement. The first perspective is local ingenuity, which focuses on local groups or individual investors. The emphasis here is on people who innovate for themselves and their communities, a process that can utilize traditional knowledge. The second 
perspective relates to local empowerment, which gives results when communities and technology developers interact, creating local groups that adopt and benefit from the technology (Lange \& Bürkner, 2018). The third perspective focuses on how grassroots innovation is sometimes seen as second class compared to innovations that channel scientific activities in the eyes of those who control capital (Muok \& Kingiri, 2015).

\section{CONCLUSION}

This research shows that the important role that Joglo Tani has played for almost 30 years is due to the social entrepreneurship of its founder, the flexible nature of organizing activities and their ability to improve program and technology appropriations by individuals and communities so that they are able to take root and are very adaptive to change. Another aspect is that Joglo Tani is able to take advantage of the momentum of agricultural development. They place themselves in the right position on the map of rural social movements. This study strengthens the conclusion that social entrepreneurship develops because of the existence of resource-rich actors to shape their legitimacy discourse by self-reflexive way. (Nicholls, 2012).

In order for grassroots innovation to be more effective in changing the socio-economic environment of the people involved, policymakers must recognize that those innovators at the grassroots level must be seen as figures who have produced valuable knowledge utilising priceless experience for solving local problems. Policy interventions can be enhanced in a number of ways, namely respecting diversity of grassroots innovation, facilitating local knowledge production processes, providing resources and space for local community involvement.

Referring to the Joglo Tani development experience, the success of informal leadership in the development, production and reproduction processes, and the provision of social space for the adoption process by local communities for values, technology, and various innovations have become determinant factors of the sustainability of this organization. On the other hand, Joglo Tani's experience proves that the role of government stakeholders in influencing the formation and appropriation of values (Hill, Kothari, \& Shea, 2010) (Hill, Kothari, \& Shea, 2010) is very important for the impact outreach of the existence of programs from the local level to the national level. The nature of voluntarism as the basis of the development of Joglo Tani remains an internal force which is the main pillar of success. This aspect may require systematic and ongoing efforts if the achievements of Joglo Tani will be used as a model.

\section{ACKNOWLEDGEMENTS}

I would like to extend my sincere gratitude to Duwiningsih, Muhammad Kautsar and Kania who had hugely supported the data collection in this research as a research assistant. I would also like to thank the Department of Anthropology of the Faculty of Cultural Science for providing department research funding with contract number: 012 / Dep.Ant / 2019 and to Adwidya Susila Yoga for the administrative support and preparation for publication as well.

\section{REFERENCES}

Amrullah, E. R., Ishida, A., Pullaila, A., \& Rusyiana, A. (2019). Who suffers from food insecurity in Indonesia? International Journal of Social Economics, 46(10), 1186-1197. https://doi.org/10.1108/IJSE-03-20190196

Ardhian, D., Adiwibowo, S., \& Sri Wahyuni, E. (2016). NGO's Roles and Strategies in the Environmental Politic Arena. Sodality: Jurnal Sosiologi Pedesaan, 4(3), 211-216. https://doi.org/10.22500/sodality. v4i3.14429

Ashari, N., Saptana, N., \& Purwantini, T. B. (2016). Potensi dan Prospek Pemanfaatan Lahan Pekarangan untuk Mendukung Ketahanan Pangan. Forum Penelitian Agro Ekonomi, 30(1), 13. https://doi.org/10.21082/ fae.v30n1.2012.13-30

Bhaduri, S., \& Kumar, H. (2011). Extrinsic and intrinsic motivations to innovate: Tracing the motivation of "grassroot" innovators in India. Mind and Society, 10(1), 27-55. https://doi.org/10.1007/s11299-0100081-2

Bhalchandra, P. U., Khamitkar, S. D., Deshmukh, N. K., Lokhande, S. N., Phulari, S. S., \& Rathod, R. P. (2010). ICT for rural developments: A review of lessons. 138-142. Retrieved from https://www.scopus.com/ inward/record.uri?eid=2-s2.0-79955129001\&partner $\mathrm{ID}=40 \& \mathrm{md} 5=\mathrm{a} 3 \mathrm{f} 3 \mathrm{a} 3 \mathrm{e} 2519 \mathrm{cfaa} 2533 \mathrm{c} 3012 \mathrm{~b} 59914 \mathrm{ba}$

Castro-Arce, K., \& Vanclay, F. (2020). Transformative social innovation for sustainable rural development: An analytical framework to assist community-based initiatives. Journal of Rural Studies, 74(November), 45-54. https://doi.org/10.1016/j.jrurstud.2019.11.010

Coppock, D. L., \& Desta, S. (2013). Collective action, innovation, and wealth generation among settled pastoral women in Northern Kenya. Rangeland Ecology and Management, 66(1), 95-105. https:// doi.org/10.2111/REM-D-11-00211.1 
D’Souza, K. C. (1984). Organizations as agents of social change. Vikalpa: The Journal for Decision Makers, 9(3), 233-248. https://doi. org/10.1177/0256090919840306

De Keersmaecker, A., Kandachar, P., Parmar, V., Vandenbempt, K., \& Baelus, C. (2013). Factors Influencing an Upscaling Process of Grassroots Innovations: Preliminary Evidence From India. Proceedings of the 8th European Conference on Innovation and Entrepreneurship, Vol 2, (Monaghan 2009), 705-714.

Dewan Ketahanan Pangan (2009). Kebijakan Umum Ketahanan Pangan 2006 - 2009. Gizi Dan Pangan, 1(1), 57-63.

Ebrashi, R. El. (2013). Social entrepreneurship theory and sustainable social impact. Social Responsibility Journal, 9(2), 188-209. https://doi.org/10.1108/ SRJ-07-2011-0013

Ghiso, Maria Paula, Campano, Gerald and Simon, R. (2013). Grassroots Inquiry: Reconsidering the Location of Innovation. Language Arts, 91(2), 105-114.

Gould, S., \& Malachowsky, J. (2013). Why Invest in Grassroots Leadership Development? In Grassroots Leadership Development:A Guide for Grassroots Leaders, Support Organizations, and Funders (pp. 8-11).

Hargreaves, T., Hielscher, S., Seyfang, G., \& Smith, A. (2013). Grassroots innovations in community energy: The role of intermediaries in niche development. Global Environmental Change, 23(5), 868-880. https://doi.org/10.1016/j.gloenvcha.2013.02.008

Hill, T. L., Kothari, T. H., \& Shea, M. (2010). Patterns of meaning in the social entrepreneurship literature: A research platform. Journal of Social Entrepreneurship, 1(1), 5-31. https://doi. org/10.1080/19420670903442079

Hilmi, M. F. (2012). Grassroots Innovation from the Bottom of the Pyramid. Current Opinion in Creativity, Innovation and Entrepreneurship, 1(2), 1-3. https:// doi.org/10.11565/cuocient.v1i2.5

Hoppe, T., Graf, A., Warbroek, B., Lammers, I., \& Lepping, I. (2015). Local governments supporting local energy initiatives: Lessons from the best practices of Saerbeck (Germany) and Lochem (The Netherlands). Sustainability (Switzerland), 7(2), 1900-1931. https://doi.org/10.3390/su7021900

Hulgård, L. (2010). Discourses of social entrepreneurshipVariations of the same theme? In SE Field. Retrieved from http://base.socioeco.org/docs/wp_10-01_hulg rd_web_.pdf\%5Cnhttp://www.emes.net/site/wpcontent/uploads/WP_10-01_Hulgaard_web_pdf

Joshi, R. G., Chelliah, J., Sood, S., \& Burdon, S. (2016). Nature and spirit of exchange and interpersonal relationships fostering grassroots innovations. The
Journal of Developing Areas, 50(6), 399-409. https:// doi.org/10.1353/jda.2016.0124

Kanagasundram, Ng, B.-K., T., Wong, C.-Y., \& Chandran, V. G. R. (2016). Innovation for inclusive development in Southeast Asia: the roles of regional coordination mechanisms. Pacific Review, 29(4), 573-602. https:// doi.org/10.1080/09512748.2015.1022590

Kumar, H., \& Bhaduri, S. (2014). Jugaad to grassroot innovations: Understanding the landscape of the informal sector innovations in India. African Journal of Science, Technology, Innovation and Development, 6(1), 13-22. https://doi.org/10.1080/20421338.20 14.895481

Laforge, J. M. L., Anderson, C. R., \& McLachlan, S. M. (2017). Governments, grassroots, and the struggle for local food systems: containing, coopting, contesting and collaborating. Agriculture and Human Values, 34(3), 663-681. https://doi.org/10.1007/s10460-0169765-5

Lange, B., \& Bürkner, H. J. (2018). Open workshops as sites of innovative socio-economic practices: approaching urban post-growth by assemblage theory. Local Environment, 23(7), 680-696. https://doi.org/10.1 080/13549839.2017.1418305

Lee, Salam. U. Fullerton, V. Kranstz, Yusuf. Y. and Henstridge, M. (2018). Indonesia Case Study: Rapid Technological Change - Challenges and Opportunities Final Report (Vol. 8). Oxford UK.

Lehner, A.-C., Koldewey, C., \& Gausemeier, J. (2018). Approach for a Pattern-Based Development of Frugal Innovations. Technology Innovation Management Review, 8(4), 14-27. https://doi.org/10.22215/ timreview/1149

Leliveld, A., \& Knorringa, P. (2018). Frugal Innovation and Development Research. European Journal of Development Research, 30(1), 1-16. https://doi. org/10.1057/s41287-017-0121-4

Ličen, N., Findeisen, D., \& Fakin Bajec, J. (2017). Communities of practice as a methodology for grassroots innovation in sustainable adult education. Andragoška Spoznanja, 23(1), 23-39. https://doi. org/10.4312/as.23.1.23-39

Liputan6 (2011). T.O Suprapto Lahirkan Konsep Joglo Tani News Liputan6.com. Retrieved September 21, 2020, from https://www.liputan6.com/news/read/332786/ to-suprapto-lahirkan-konsep-joglo-tani

Magnusson, D. (2018). Going back to the roots: the fourth generation of Swedish eco-villages. Scottish Geographical Journal, 134(3-4), 122-140. https:// doi.org/10.1080/14702541.2018.1465199

Magnusson, D., \& Palm, J. (2019). Come together-the development of Swedish energy communities. Sustainability (Switzerland), 11(4), 1-19. https:// doi.org/10.3390/su11041056 
Martiskainen, M., Heiskanen, E., \& Speciale, G. (2018). Community energy initiatives to alleviate fuel poverty: the material politics of Energy Cafés. Local Environment, 23(1), 20-35. https://doi.org/10.1080/ 13549839.2017.1382459

Maspary (2011). Ada Apa di Joglo Tani. Retrieved September 21, 2020, from http://www.gerbangpertanian. com/2011/04/ada-apa-di-joglo-tani.html

Maxim Vlasov, K. J. B. and Z. V. D. (2018). Entrepreneurship for resilience: embeddedness in place and in translocal grassroots networks. Journal of Enterprising Communities: People and Places in the Global Economy, 12(3), 374-394.

Meagher, K. (2018). Cannibalizing the Informal Economy: Frugal Innovation and Economic Inclusion in Africa. European Journal of Development Research, 30(1), 17-33. https://doi.org/10.1057/s41287-017-0113-4

MNCTV (2014a). T.O Suprapto “ Pembina Joglo Tani “ MNCTV Pahlawan Untuk Indonesia 2014 - YouTube. Retrieved September 22, 2020, from https://www. youtube.com/watch? $\mathrm{v}=\mathrm{GmpxVOOVPiE}$

MNCTV (2014b). T.O Suprapto “Pembina Joglo Tani “ MNCTV Pahlawan Untuk Indonesia 2014 - YouTube. Retrieved September 21, 2020, from https://www. youtube.com/watch? $\mathrm{v}=\mathrm{Gmpx}$ VOOVPiE

Morrar, Rabeh, Arman, Husam and Mousa, S. (2017). the Fourth Industrial Revolution (Industry 4.0) a Social Innovation Perspective. Technology Innovation Management Review, 7(11), 12-21. https://doi. org/10.25073/0866-773x/97

Muok, B. O., \& Kingiri, A. (2015). The role of civil society organizations in low-carbon innovation in Kenya. Innovation and Development, 5(2), 207-223. https:// doi.org/10.1080/2157930X.2015.1064558

Nakamura, Y. T., \& Horimoto, M. (2020). A Conceptual Framework for Developing Women Social Entrepreneurs in Japan. Advances in Developing Human Resources, 22(2), 164-175. https://doi. org/10.1177/1523422320907046

Nicholls A. (2012) Postscript: The Legitimacy of Social Entrepreneurship: Reflexive Isomorphism in a Pre-paradigmatic Field. In Gidron B., Hasenfeld Y. (eds) Social Enterprises, pp. 222247. London: Palgrave Macmillan. https://doi. org/10.1057/9781137035301_11

Nirmala, C., Yukti, D., \& Wahyono, S. B. (2020). Proses pembelajaran dalam komunitas Joglo Tani. Jurnal Inovasi Teknologi Pendidikan, 7(1), 34-41.

Nolden, C. (2013). Governing community energy-Feedin tariffs and the development of community wind energy schemes in the United Kingdom and Germany. Energy Policy, 63, 543-552. https://doi. org/10.1016/j.enpol.2013.08.050

Obie, M., Yusuf, I. D. S., \& Sumai, S. (2019). Empowerment of Palm Sugar Peasants at the Forest Edge of Bogani Nani Wartabone National Park, Indonesia: A Study of Problems, Local Potentials, and Priority Ideas Towards Empowered Community. Environment and Natural Resources Research, 9(1), 77-90. https://doi. org/10.5539/enrr.v9n1p77

Pansera, M., \& Martinez, F. (2017). Innovation for development and poverty reduction: an integrative literature review. Journal of Management Development, 36(1), 2-13. https://doi.org/10.1108/ JMD-02-2015-0013

Ross, T., Mitchell, V. A., \& May, A. J. (2012). Bottom-up grassroots innovation in transport: Motivations, barriers and enablers. Transportation Planning and Technology, 35(4), 469-489. https://doi.org/10.108 0/03081060.2012.680820

Santos, F. M. (2012). A Positive Theory of Social Entrepreneurship. Journal of Business Ethics, 111(3), 335-351. https://doi.org/10.1007/s10551-012-14134

Schillo, R. S., \& Robinson, R. M. (2017). Inclusive Innovation in Developed Countries: The Who, What, Why, and How. Technology Innovation Management Review, 7(7), 34-46. Retrieved from https://timreview.ca/sites/default/files/article_PDF/ SchilloRobinson_TIMReview_July2017.pdf

Seyfang, G., \& Longhurst, N. (2016). What influences the diffusion of grassroots innovations for sustainability? Investigating community currency niches. Technology Analysis and Strategic Management, 28(1), 1-23. https://doi.org/10.1080/09537325.2015.1063603

Seyfang, G., \& Smith, A. (2007). Grassroots innovations for sustainable development: Towards a new research and policy agenda. Environmental Politics, 16(4), 584603. https://doi.org/10.1080/09644010701419121

Shukla, S. R., \& Sinclair, A. J. (2010). Strategies for self-organization: Learning from a village-level community-based conservation initiative in India. Human Ecology, 38(2), 205-215. https://doi. org/10.1007/s10745-010-9301-y

Singh, R. K., Singh, H. N., Singh, V. N., Singh, A., Singh, S., Singh, N., \& Singh, A. (2009). Helping farmers adapt to climate change : The NEFORD way. Indian Journal of Genetics and Plant Breeding, 69(4), 319-324. Retrieved from https://www.scopus.com/ inward/record.uri?eid=2-s2.0-80053042707\&partner $\mathrm{ID}=40 \& \mathrm{md} 5=5515181 \mathrm{eec} 1140 \mathrm{~d} 3$ aaea $12 \mathrm{f} 80 \mathrm{c} 712533$

Smith, A. (2016). Alternative technology niches and sustainable development. Innovation: Management, Policy and Practice, 18(4), 468-484. https://doi.org /10.1080/14479338.2016.1265047

Smith, A., Fressoli, M., \& Thomas, H. (2014). Grassroots innovation movements: Challenges and contributions. Journal of Cleaner Production, 63, 114-124. https:// 
doi.org/10.1016/j.jclepro.2012.12.025

Smith, A., Hargreaves, T., Hielscher, S., Martiskainen, M., \& Seyfang, G. (2016). Making the most of community energies: Three perspectives on grassroots innovation. Environment and Planning A, 48(2), 407-432. https:// doi.org/10.1177/0308518X15597908

Smith, A., \& Stirling, A. (2016). Grassroots Innovation and Innovation Democracy. In STEPS Working Paper 89.

Sparrow, R., \& Widyanti, W. dan A. S. (2010). Social Health Insurance for the Poor: Targeting and Impact of Indonesia's Askeskin Program. The SMERU Research Institute.

Sunarno (2011). Bertani dengan Hati: JOGLO TANI ORGANIK BERKELANJUTAN. Retrieved September 21, 2020, from http://timbuljoglo. blogspot.com/2011/03/profil-lembaga-talesingsedyayu-tinulad.html)

Syadiah, L. (2015). Kontribusi Joglo Tani Di Mandungan Margoluwih Seyegan Sleman Yogyakarta Dalam Peningkatan Peran Pemuda Pada Pembangunan Sektor Pertanian Guna Mewujudkan Ketahanan Pangan. Jurnal Ketahanan Nasional, 21(3), 156-163. https://doi.org/10.22146/jkn.22175

Tracey, P., \& Stott, N. (2017). Social innovation: a window on alternative ways of organizing and innovating. Innovation: Management, Policy and Practice, 19(1), 51-60. https://doi.org/10.1080/14479338.20 16.1268924
TV, B. S. (2012). Belajar Kemandirian Pangan dari Joglo Tani - YouTube. Retrieved September 22, 2020, from https://www.youtube.com/watch?v=D75QZIk3huc

Ustyuzhantseva, O. V. (2015). Institutionalization of grassroots innovation in India. Current Science, 108(8), 1476-1482.

Verma, S., Tsephal, S., \& Jose, T. (2004). Pepsee systems: Grassroots innovation under groundwater stress. Water Policy, 6(4), 303-318.

Widiara, Aero, Rosyida Isma, Gandj Rajib, and Muswar, H. S. (2009). Peasant Empowerment Through Social Capital Reinforcement: Road to Sustainable Organic Agriculture Development (Case Study: Indonesian Peasant Union, Ciberum Situleuntik Village, Drabmaga Bogor, West Java). Asian Journal of Food and Agro-Industry, Special Issue, 297-306.

Yagnick, N. S., Singh, R., Tripathi, M., Mohindra, S., Deora, H., Suri, A., \& Gupta, S. K. (2019). Need for Grass Root Innovation in Developing Countries: Case for Stationary Binder Clips in Scalp Hemostasis. World Neurosurgery, 121, 222-226. https://doi. org/10.1016/j.wneu.2018.09.182

Ziegler, R. (2017). Citizen Innovation as Niche Restoration-A Type of Social Innovation and Its Relevance for Political Participation and Sustainability. Journal of Social Entrepreneurship, 8(3), 338-353. https://doi. org/10.1080/19420676.2017.1364286 